\title{
Interacting effects of deposit feeding and tidal resuspension on benthic microalgal community structure and spatial patterns
}

\author{
Craig Plante*, Emily Frank, Patricia Roth \\ Department of Biology, Grice Marine Laboratory, College of Charleston, Charleston, South Carolina 29412, USA
}

\begin{abstract}
Benthic microalgae (BMA) are important primary producers constituting an essential component of nearshore food webs. BMA also release extracellular polymeric secretions that stabilize sediments. Primary objectives of our research were to assess the separate and interactive effects of biotic and abiotic disturbances on structure and spatial patterns of microalgal communities in shallow-water sediments. Using field comparative studies, we characterized the effects of 2 prominent types of disturbance: macroinvertebrate ingestion and tidal resuspension. BMA biomass and composition in fecal materials from the enteropneust Balanoglossus aurantiacus and sediments were followed through time using fluorometry and molecular techniques (PCR-DGGE analysis of 18S rDNA and sequencing). We also examined the effects of disturbance on spatial patterns of BMA biomass, diversity, and composition over the larger sedimentary landscape using correlative studies. Deposit-feeder ingestion was found to significantly reduce BMA biomass and alter BMA composition, although qualitative changes were comparatively less remarkable. A significant difference was also found between average biomass before and after tidal immersion. Spatial autocorrelation revealed heterogeneity in BMA distribution during low tide, and that this spatial patterning correlated with $B$. aurantiacus fecal coils. Samples taken after tidal immersion showed no patchiness, nor was there a correlation between BMA biomass and pre-immersion fecal cover. In intertidal sediments, the qualitative and quantitative impacts of deposit feeding, and the resulting landscape-scale patchiness, appear to be short-lived due to erasure by frequent tidal resuspension.
\end{abstract}

KEY WORDS: Disturbance $\cdot$ Spatial autocorrelation $\cdot$ DGGE $\cdot$ Diatom $\cdot$ Intertidal $\cdot$ Beach

\section{INTRODUCTION}

Benthic microalgae (BMA) are important primary producers in intertidal and shallow, subtidal sediments (Underwood \& Paterson 1993, de Jonge 1994), comprising a vital food resource for heterotrophs (e.g. Miller et al. 1996). In sandy and mudflat environments, diatoms are usually the dominant representatives in BMA communities (Meadows \& Anderson 1968). These benthic diatoms release extracellular polymeric secretions (EPS) that inhibit resuspension of sediments and associated biota from tidal currents or waves (Holland et al. 1974, Underwood \& Paterson 1993, Miller et al. 1996). EPS also serve as a carbon source for microbes and deposit-feeding invertebrates (Decho \& Lopez 1993). Consequently, the removal of EPS or the diatom producers, e.g. by invertebrate feeding, de-stabilizes sediments (Austen et al. 1999).

In marine soft-bottom habitats, disturbance can be an important factor structuring benthic communities 
(Brey 1991). A disturbance removes organisms and has been defined as 'any discrete event in time that disrupts ecosystem, community or population structure and changes the physical environment' (White \& Pickett 1985). Although sometimes thought of as a predator-prey interaction, we argue here that treatment of deposit-feeder ingestion as a disturbance is more appropriate because it acts over larger spatial scales (relative to BMA), influences communities as opposed to individuals, and is less selective. Moreover, deposit feeding disrupts the physical environment as well as the biota (Rhoads \& Boyer 1982, Katrak \& Bird 2003).

In sediments, deposit feeding can be a dominant type of disturbance for micro-organisms (Sommer 2000, Hagerthey et al. 2002, Plante \& Wilde 2004). It is widely accepted that deposit feeders consume and assimilate benthic diatoms with high efficiency (Yingst 1976, Nielsen \& Kofoed 1982), and numerous prior studies have documented significant BMA biomass reductions in the field due to grazing by a taxonomically diverse array of deposit feeders (Bianchi \& Levinton 1981, Smith et al. 1996, Sommer 2000). Quantitative or qualitative changes in BMA due to gut passage and defecation produce patchy distributions and influence diversity patterns. As examples, grazing by Corophium volutator or Hydrobia ulvae on intertidal diatoms increased or decreased species diversity under different temperature or nutrient regimes (Hagerthey et al. 2002), and McClatchie et al. (1982) demonstrated reduced cell biomass but higher diatom species richness at highest snail (Amphibola crenata) densities. Hillebrand (2008) employed a meta-analysis to conclude that grazing generally increases relative spatial variability in microalgal biomass. Experiments by Sommer (2000) showed that 2 benthic invertebrate species, Idothea chelipes and Littorina littorea, differed in their spatial pattern, but not intensity or selectivity, of grazing on BMA. The spatial heterogeneity of grazing pressure may therefore be more important for maintenance of diversity than the mean intensity of grazing.

Physical disturbances are also prominently considered when evaluating BMA ecology (MacIntyre et al. 1996). In soft-bottom, intertidal, and shallow subtidal habitats, tidal resuspension can homogenize surficial sediments. However, twice-daily periods of resuspension may not be disturbances for epipelic diatoms and other BMA. Sediment transport due to tidal changes is cyclical and predictable on short time scales (relative to BMA generation times) so BMA in such habitats are adapted to these events. Both vertical migrations and adhesion to particles may reduce the proclivity for benthic diatoms to resuspend (MacIntyre et al. 1996, Shimeta \& Sisson 1999).

Common to landscape ecology studies is a focus on the reciprocal relationship between spatial heterogeneity and ecological processes. Disturbance remains prominent in landscape studies, and current research questions emphasize understanding the interactions among different kinds and scales of disturbance (Turner 2005). Interactions among small-scale biotic disturbances and larger-scale abiotic disturbance are well established for terrestrial grassland systems, and to a lesser extent, select forest ecosystems. The interactions between large mammal grazing and fire (Harrison et al. 2003, Collins \& Smith 2006, Veen et al. 2008) as well as animal burrowing and fire (Rogers \& Hartnett 2001) in grasslands illustrate dissimilar effects on species composition and diversity from biotic and abiotic disturbances, and associated complex interactions. To our knowledge similar studies examining multiple drivers and their interactions in marine intertidal habitats have not been performed, representing a critical gap in our understanding of the ecology of these important systems.

We tested whether (1) deposit feeding causes spatial heterogeneity in BMA biomass and (2) tidal resuspension homogenizes BMA biomass (eliminates patchiness caused by biotic disturbance). We also tested for differences in BMA community structure in fecal and surface sediments, both pre- and post-tidal immersion.

\section{MATERIALS AND METHODS}

\section{Study site}

Sediment and fecal samples of the golden acorn worm Balanoglossus aurantiacus (Hemichordata: Enteropneusta) were collected in July 2008 at Breach Inlet $\left(32^{\circ} 46^{\prime} 23^{\prime \prime} \mathrm{N}, 79^{\circ} 48^{\prime} 53^{\prime \prime} \mathrm{W}\right)$, a beach on the north end of Sullivans Island, South Carolina, USA. Located between a rock jetty to the south and the foundation of a bridge to the north, the intertidal sandflat is considered a semi-protected beach. Strong currents are common throughout the semidiurnal tidal cycle due to the funneling of the ocean into a relatively narrow space between 2 barrier islands. The median grain size at the site is $\sim 171 \mu \mathrm{m}$ (Wilde \& Plante 2002). B. aurantiacus is a common sedimentdweller at this site, with fecal mounds visible in the intertidal zone at low tide. These large worms (up to $1 \mathrm{~m}$ in length) burrow into the sand, creating a feeding funnel through which sediment is subducted into 
the mouth. After the sediment has moved through the digestive system, a characteristic fecal coil is deposited at the other end of the burrow.

\section{Field collection}

To compare the structure of the BMA community in fecal coils with that in the surrounding sediment, samples were collected with either spatulas or a syringe with the Luer-end cut off (Wilde \& Plante 2002). Surface sediment was collected only to $3 \mathrm{~mm}$ deep, as light limitations prevent diatoms from photosynthesizing deeper than 2 to $3 \mathrm{~mm}$ (MacIntyre et al. 1996). Surface sediment was collected $15 \mathrm{~cm}$ from the fecal mounds. Fecal sediment was collected directly from existing fecal coils. All of the samples (0.5 to $1.5 \mathrm{~g}$ of sediment each) were transferred directly into sterile $15 \mathrm{ml}$ centrifuge tubes, capped tightly, and stored over ice until returned to the lab. For long-term storage, samples were kept at $-20^{\circ} \mathrm{C}$, covered in foil.

To further establish that physical appearance (sediment color and elevation) of fecal mounds corresponded with disturbance of BMA, 8 sediment samples were collected along 1 transect line leading from the top of each of 5 fecal mounds (where fresh fecal material was visible) out to $14 \mathrm{~cm}$ and subsequently analyzed for BMA biomass. Each transect line was placed at a randomly chosen angle from the water line and samples were collected at $0,2,4,6,8,10,12$, and $14 \mathrm{~cm}$. The appearance of each sampling site was recorded (i.e. the color and topography of each sampling site in comparison to surrounding sediment).

To examine physical disturbances to the BMA community, sampling was conducted at 2 times in the tidal cycle, allowing for the examination of differences in BMA community structure before and after tidal resuspension. Initial sampling of fecal and surface sediment was done at low tide, just prior to immersion. Each fecal coil was then marked using 2 pieces of PVC piping, driven into the sediment $10 \mathrm{~cm}$ to either side of the fecal coil, in a line parallel to the water's edge, such that water flow around the poles did not erode the sediment near the fecal coil. Sampling was repeated during early ebb tide, following a single tidal immersion. Samples were collected from the surrounding surface sediment and from the original location of the fecal coil, even if the fecal coil was no longer visible. All pre- and post-immersion fecal and sediment samples were analyzed for BMA biomass ( $\mathrm{n}=12$ for each sample type), with a subset $(n=3)$ also subject to molecular analysis.

\section{Spatial autocorrelation field collection}

For the study of spatial heterogeneity, a modified version of the collection methods of Wilde \& Plante (2002) was used. A transect was marked in the intertidal, near and parallel to the water line at low tide. A $1 \times 1 \mathrm{~m}$ PVC quadrat was haphazardly placed along the transect line to include several fecal coils within its bounds. Within the PVC quadrat, a grid containing $8 \times 8$ squares (each measuring $2 \times 2 \mathrm{~cm}$ ) was placed in 2 of the corners and in the center of the opposite side (Fig. 1). Sampling within each small square allowed for samples to be taken at varied and easily determined distances from one another. To examine patterns over even larger (meter or decameter) spatial scales, a second $1 \times 1 \mathrm{~m}$ PVC square was placed $20 \mathrm{~m}$ from the first (down the transect line) and samples were taken from a 64-sample grid in the center of the square. Before destructive sampling of sediment was conducted, the percent fecal cover (as recognized by sediment color and elevation) of each of the $2 \times 2 \mathrm{~cm}$ squares in the 64-square grid was noted. Sampling for sediment chlorophyll a (chl a) was performed as described in 'Field collection'. Samples were placed into $1.5 \mathrm{ml}$ microcentrifuge tubes, stored over ice until returned to the laboratory, and then stored at $-20^{\circ} \mathrm{C}$ until analysis.

To examine effects of tidal immersion on spatial pattern, 2 additional $1 \times 1 \mathrm{~m}$ plots were selected, $20 \mathrm{~m}$ apart along the transect line. At the first low tide, percent fecal cover of each of the $2 \times 2 \mathrm{~cm}$ squares in the 64-sample grids was noted and PVC poles were placed $0.5 \mathrm{~m}$ from the corners of the $1 \times 1 \mathrm{~m}$ square to mark its exact location. Following a single period of immersion, and immediately upon subsequent aerial re-exposure, samples for chlorophyll measurement were again collected, according to the procedures described in 'Field collection'.

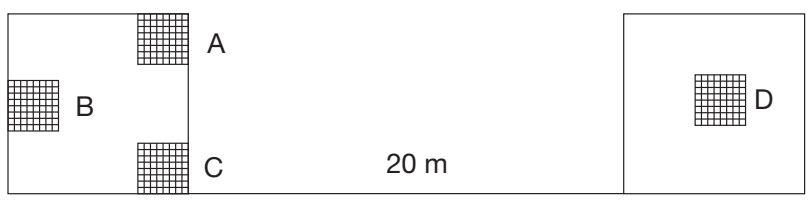

Fig. 1. Layout for spatial autocorrelation sampling consisted of 2 beach quadrats $(1 \times 1 \mathrm{~m}$, PVC) placed at opposite ends of a $20 \mathrm{~m}$ transect line. One quadrat contained three 64sample square grids (A to $C$ ); the other contained only one 64-sample square grid (D). Grids A to D were collected before tidal immersion. A similar set-up was used for Grids $\mathrm{E}$ to $\mathrm{H}$, which were collected after tidal immersion. Not to scale 


\section{Analytical methods}

\author{
Chlorophyll a
}

A modified version of the procedure described by Easley et al. (2005) was used for chl a measurement. Wet sediment ( 0.3 to $0.5 \mathrm{~g}$ ) was placed in a vial with $10 \mathrm{ml}$ of $90 \%$ acetone, wrapped in foil, and extracted at $-20^{\circ} \mathrm{C}$ for 24 to $48 \mathrm{~h}$. A fluorometer (Turner Designs TD-700) was used to measure the chl a content $\left(\mu \mathrm{g} \mathrm{l}^{-1}\right)$. Remaining sediment was filtered onto $4.25 \mathrm{~cm}$ diameter glass fiber filters, dried at least $12 \mathrm{~h}$ at $60^{\circ} \mathrm{C}$, then weighed in order to normalize chl a per gram of dry sediment.

\section{DNA extraction}

DNA was extracted using a modified version of the bead-mill method (Aguilera et al. 2006): $~ 1 \mathrm{~g}$ of sample was combined with $0.1 \mathrm{~mm}$ zirconia-silica beads $(\sim 2 \mathrm{~g}), 250 \mu \mathrm{l}$ of extraction buffer $(1 \mathrm{M} \mathrm{NaCl}$, $70 \mathrm{mM}$ Tris, $30 \mathrm{mM}$ EDTA), and $500 \mu \mathrm{l}$ of $100 \mathrm{mM}$ $\mathrm{HNa}_{2} \mathrm{PO}_{4}(\mathrm{pH}$ 8) prior to two $20 \mathrm{~s}$ runs at $2500 \mathrm{fpm}$ on a Mini Beadbeater (Biospec Products). DNA was precipitated (3 M sodium acetate:isopropanol $=1: 6$, $\mathrm{v} / \mathrm{v})$, cleaned (series of ethanol washes), resuspended ( $50 \mu \mathrm{l}$ sterile water), and then stored at $4^{\circ} \mathrm{C}$ for $>12 \mathrm{~h}$. Concentration and size was determined on a $1 \%$ agarose gel in conjunction with a low DNA mass ladder (BioRad EZ Load Ladder). If needed, a DNA purification kit (Promega Wizard PCR Preps DNA Purification System) was used according to the manufacturer's instructions.

\section{PCR-DGGE}

Because numerous studies have demonstrated that epipelic diatoms dominate in this type of habitat (McClatchie et al. 1982, Underwood \& Paterson 1993, Grippo et al. 2010), diatom-specific primers STRAM 9F (5 -CTGCCAGTAGTCATACGCTC-3) and 517 Rgc-clamp (5 -GCCCGGGGCGCGCCCCGGGCGG GGCGGGGGACCAGACTTGCCCTC-3 ) were used to amplify the 18S rRNA gene according to the PCR protocols of Cary et al. (2006). Gel electrophoresis in $1.0 \%$ agarose stained with ethidium bromide was used to visualize the amplified DNA. The products were quantified using the Quantity One (Bio-Rad Laboratories) software package and a low mass ladder. When final concentration of the amplified product was below target levels, the PCR product was used as template for an additional 7 cycles of the standard protocol (with accompanying initial denaturing and extension steps).

For DGGE, a $6 \%$ polyacrylamide gel (acrylamide: bisacrylamide $=37.5: 1$ ) with a denaturing gradient of 25 to $40 \%$ (100\%: $7 \mathrm{M}$ urea and $40 \%$ v/v deionized formamide) was loaded with $200 \mathrm{ng}$ DNA per well. When necessary, PCR products were combined and concentrated using ethanol precipitation. A Versa Doc Imaging System and accompanying Quantity One software were employed for DGGE gel acquisition and analysis. After removing background intensity from all lanes (via the rolling disk method), the software detects different bands, their density in the lanes, and matches them to similar bands in other lanes on the same gel. This software was also used to identify and analyze the bands present in each lane, as described by Stocum \& Plante (2006).

Bands of interest were extracted from the gel using a sterile pipette tip and stored in $10 \mu \mathrm{l}$ Tris-HCl (10 mM, pH 8.5) at $4^{\circ} \mathrm{C}$ until sequence analysis was performed. DGGE primers were used for sequencing (Beckman Coulter CEQ 8000 Genetic Analysis System) minus the GC-clamp. Test samples, consisting of the brightest bands from a fecal and surface sediment samples (both pre- and post-tidal immersion), were examined to verify source DNA as diatom in nature. Reads approximately 300 to 400 nucleotides long were evaluated using the GenBank blastn database (Altschul et al. 1990), and results with $>96 \%$ maximum identities were considered.

\section{Statistical analysis}

ANOVA was used to test for differences in biomass (chl a), DGGE band number $(S)$, and species diversity between sample type (fecal and sediment), and between samples before and after tidal immersion. Shannon-Wiener diversity indices $\left(H^{\prime}\right)$, incorporating band number and relative band intensities, were calculated using PRIMER v6 (Primer-E). The JMP 7.0 software package (SAS Institute) was used to perform the ANOVA calculations. Further, the DGGE banding patterns were used to create an unweighted similarity matrix using the Quantity One software package, which was then analyzed by nonmetric multidimensional scaling (NMDS) using PRIMER v6 software. Applied to DGGE data, an NMDS plot shows every banding pattern as a single point from which relative changes in community structure can be visualized (van Hannen et al. 1999). Additionally, analysis of similarity (ANOSIM) tests were used to 
compare community composition among sample types (Rees et al. 2004, Powell et al. 2005). Both 2-way (crossed design, with sample type and time as factors) and 1-way ANOSIM as described by Clarke \& Green (1988) were performed on each gel similarity matrix. Within the PRIMER v6 tutorial, Clarke \& Gorley (2006) interpret values of $R>0.75$ as well separated, $>0.5$ as overlapping but different, $>0.25$ as barely separable, and $<0.25$ (including negative values) as indistinguishable. Both $R$-statistics and significance levels generated from ANOSIM were used to assess differences among communities; however, with small numbers of replicates, and thus few possible permutations, p-values can be less useful than $R$-statistics. Spatial autocorrelation calculations were performed to test for spatial heterogeneity as described by Wilde \& Plante (2002). SAM v3.0 was used to perform spatial autocorrelation and Pearson's correlation analysis (Rangel et al. 2006). The latter allows for correction of degrees of freedom due to spatial autocorrelation. The coefficient Moran's I was used to construct correlograms between chlorophyll values and inter-sample distances (Sandulli \& Pinckney 1999).

\section{RESULTS}

Fecal sediments contained far less chl a than did surrounding sediment (Fig. 2). In samples taken prior to tidal immersion, a significant reduction ( $91.7 \%)$ was found between microalgal biomass ( $\mathrm{chl}$ a) in fecal versus surface sediment samples $(p<0.001)$. Tidal immersion also strongly affected chl a content.

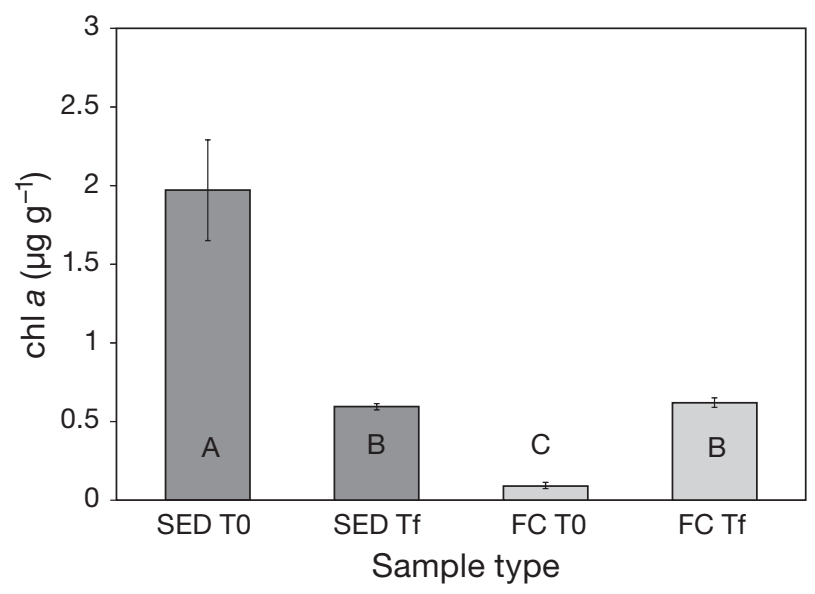

Fig. 2. Chlorophyll a content (mean $\pm S E M, n=12$ ) of surface sediment (SED, dark grey bars) and fecal (FC, light grey bars) samples pre- (T0) and post-tidal (Tf) immersion. Different letters on or above bars indicate statistically different $(\alpha=0.05)$ mean values
Significant differences in microalgal biomass were observed between surface sediment pre- and posttidal immersion $(\mathrm{p}<0.001)$, and between fecal material pre- and post-tidal immersion $(\mathrm{p}<0.001)$. No significant difference existed between fecal and surface sediment biomass after tidal immersion $(p=0.388)$.

Samples taken at $2 \mathrm{~cm}$ intervals along transects across fecal patches showed significant global differences $(p<0.001)$. A Tukey-Kramer honestly significant difference test revealed that there was no significant difference between chl a content of the patch center $(0 \mathrm{~cm})$ and $2 \mathrm{~cm}(\mathrm{p}=0.980$; Fig. 3$)$, but these 2 levels were significantly different than those collected at $6,8,10,12$, and $14 \mathrm{~cm}$, all of which were indistinguishable from one other $(p>0.263$ for all such comparisons). The chl a value at $4 \mathrm{~cm}$ was not significantly different from either of the other 2 groups ( $p>0.188$ for all such comparisons). The reduced chl a content of the sediment at 0,2 , and $4 \mathrm{~cm}$ corresponded to the visual boundaries of the fecal mounds.

Autocorrelation analysis revealed spatial heterogeneity in BMA biomass at low tide (Fig. 4A). A significant positive autocorrelation existed at the smallest spatial scale $(\sim 2.4 \mathrm{~cm}, \mathrm{p}<0.0001)$. Significant negative autocorrelation existed at $\sim 43.7 \mathrm{~cm}(\mathrm{p}<$ $0.001), \sim 73.6 \mathrm{~cm}(\mathrm{p}<0.001)$, and $78.6 \mathrm{~cm}(\mathrm{p}=0.043)$ between sampling grids. As sampling sites became further apart, a negative correlation was seen, though not always significant. Autocorrelation values again were positive at larger distances between sampling sites (Fig. 4A). Patch size was approximated to be $\sim 7 \mathrm{~cm}$ in radius (inter-sample distance at which correlogram switches from positive to negative Moran's Ii Sandulli \& Pinckney 1999).

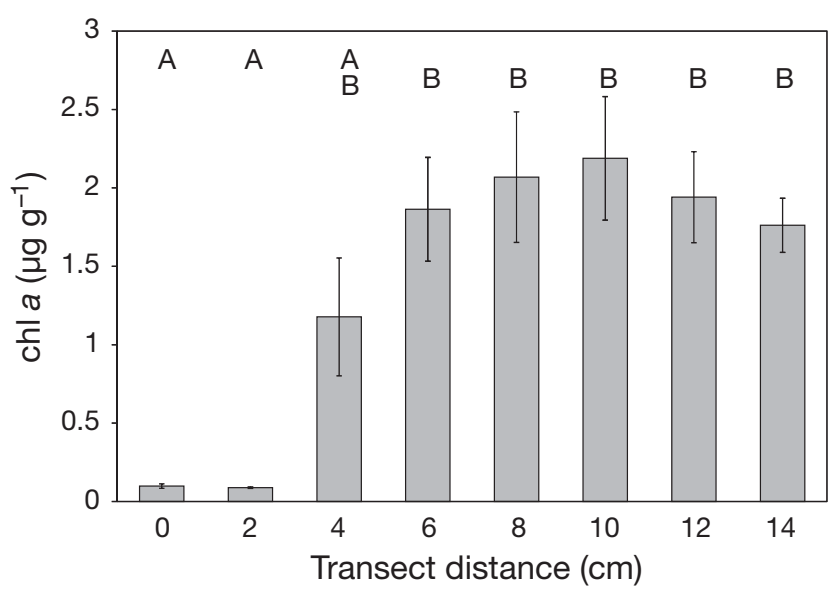

Fig. 3. Sediment chlorophyll a content (mean $\pm \mathrm{SE}, \mathrm{n}=5$ ) at $2 \mathrm{~cm}$ intervals along transects, starting at center of Balanoglossus aurantiacus fecal mounds. Different letters indicate significantly different $(\alpha=0.05)$ mean values 


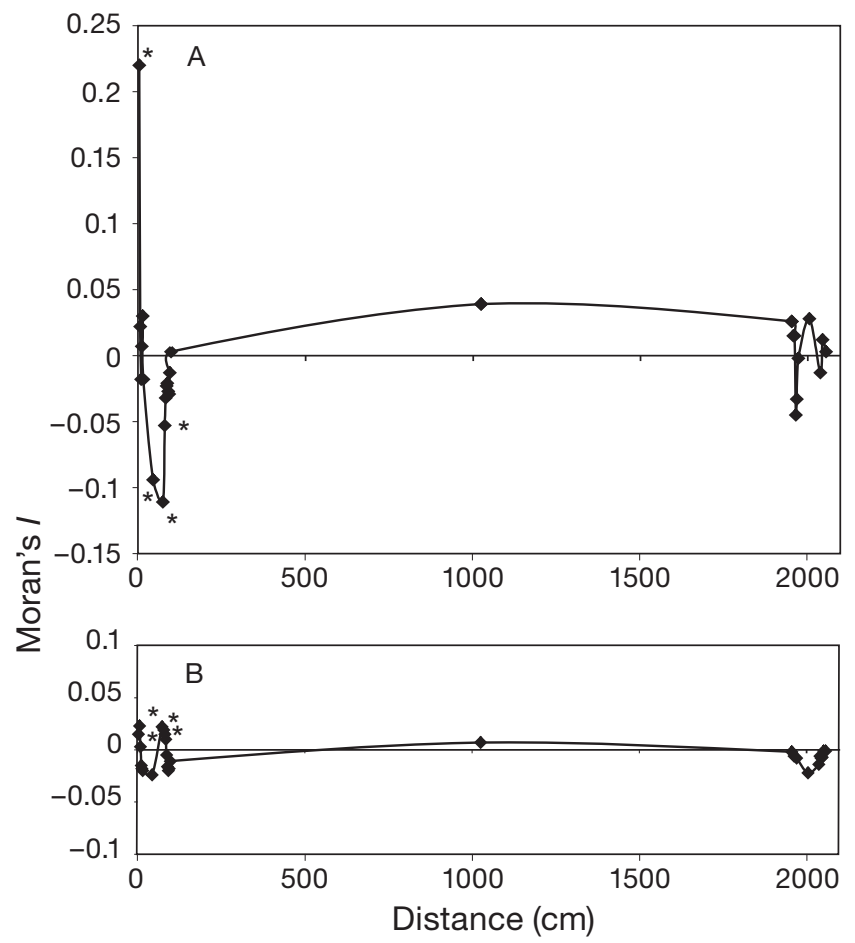

Fig. 4. Moran's I values for sediment chlorophyll a content (A) before and (B) after tidal immersion. * Significant values $(\alpha=0.05)$

After tidal immersion, a different spatial pattern was observed (Fig. 4B). Significant positive autocorrelations were detected at diverse spatial scales: $\sim 2.4 \mathrm{~cm}(\mathrm{p}=0.047), \sim 6.0 \mathrm{~cm}(\mathrm{p}=0.004), \sim 73.3 \mathrm{~cm}$ $(\mathrm{p}=0.047)$, and $\sim 78.6 \mathrm{~cm}(\mathrm{p}=0.047)$. While these correlations were significant, the p-values closely approached $\alpha=0.05$ in several cases, and the autocorrelation coefficients were small relative to the preimmersion values, indicating weaker relationships.

Surface plots of chl a content and percent fecal cover values visually represent the correspondence between these 2 variables (Fig. 5). The inverse relationship is especially evident in Grid A (Fig. 5A). Although the absolute loss in BMA biomass is less remarkable, the negative relationship between chl a and fecal cover is also evident in Grids B and D (Fig. 5B,D), whereas no chl a trough is seen in the grid that contained no Balanoglossus aurantiacus fecal mounds (Fig. 5C). Before tidal immersion, a significant negative correlation between chl $a$ and percent fecal cover was observed $(r=-0.199$, $p=0.014)$. Following tidal immersion, no significant correlation was found ( $p=0.697$ ). Visually, no correspondence is evident in surface plots between pre-immersion fecal cover and post-tidal immersion chl a contents (Fig. 6).
DNA sequencing of select DGGE bands seemed to confirm primer specificity. In each case $(n=5)$, highest percent similarity (96 to $98 \%$ ) when compared to the GenBank blastn database was found to be with diatom species. A mean of 11 DGGE bands resulted from pre-immersion fecal samples, whereas postinundation fecal samples had 15.3 bands, and pre(13.7) and post- (13.3) immersion sediment samples exhibited intermediate band numbers; however, band number did not differ significantly either for sample type $(p=0.792)$ or time $(p=0.141)$. Similarly, mean Shannon-Wiener diversity indices ranged between 2.17 (pre-immersion fecal samples) and 2.51 (postimmersion fecal samples), with pre- and postimmersion sediment values in between (2.48 and 2.41 , respectively). These diversity indices did not differ significantly, either by sample type $(p=0.323)$ or time ( $p=0.238)$. Although the majority of DGGE bands were common to all sample types, banding patterns were clearly distinguishable by time $(R=$ 0.519, p = 0.004; ANOSIM), but less clearly separable by sample type $(R=0.278, \mathrm{p}=0.120)$. NMDS analysis revealed that pre-immersion fecal samples were distinct from all other sample types (Fig. 7). When analyzed using 1-way ANOSIM, pairwise comparisons within the ANOSIM corroborated these distinctions. Pre-immersion fecal samples were distinct from all other sample types ( $R>0.481$ for all comparisons), whereas fecal samples after inundation were not distinct from sediment before or after tidal immersion ( $R=0.074$ for both comparisons), nor did the sediment samples differ $(R=0.111)$.

\section{DISCUSSION}

In the present study we observed $\sim 92 \%$ BMA removal due to Balanoglossus aurantiacus gut passage. This compares well to 83 and $94 \%$ removal by the same species at the same beach in the summers of 2006 and 2007, respectively (Plante et al. 2010). This reduction between ingesta and egesta falls at the high end of the range noted for other deposit-feeding taxa (47 to 93\%; Fenchel 1972, Hargrave 1970, Kofoed 1975, Yingst 1976, Plante et al. 2010). Generally, studies that have compared BMA biomass in plots with and without diverse deposit feeders have demonstrated the capacity to substantially reduce BMA biomass over larger sedimentary landscapes (Bianchi \& Levinton 1981, Miller et al. 1996, Hagerthey et al. 2002).

Spatial autocorrelation analysis demonstrates that this biological disturbance results in BMA biomass 
A
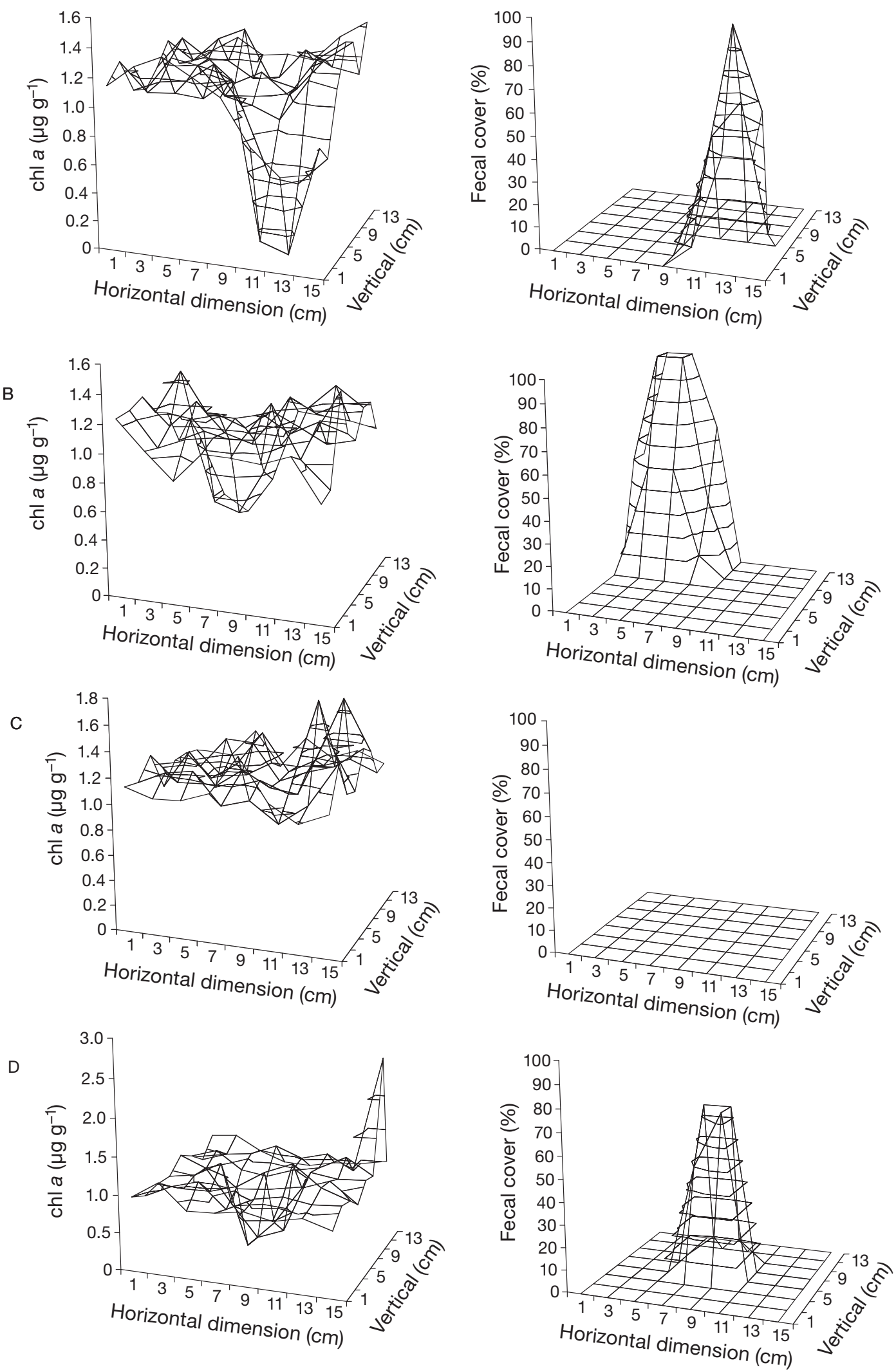

Fig. 5. Surface plots showing the sediment chlorophyll a content and corresponding fecal cover of four $16 \mathrm{~cm} \times 16 \mathrm{~cm}$ sampling grids before tidal immersion (Grids A to D here and in Fig. 1). Horizontal and vertical dimensions refer to along-transect and perpendicular (up-beach) aspects of each grid, respectively 

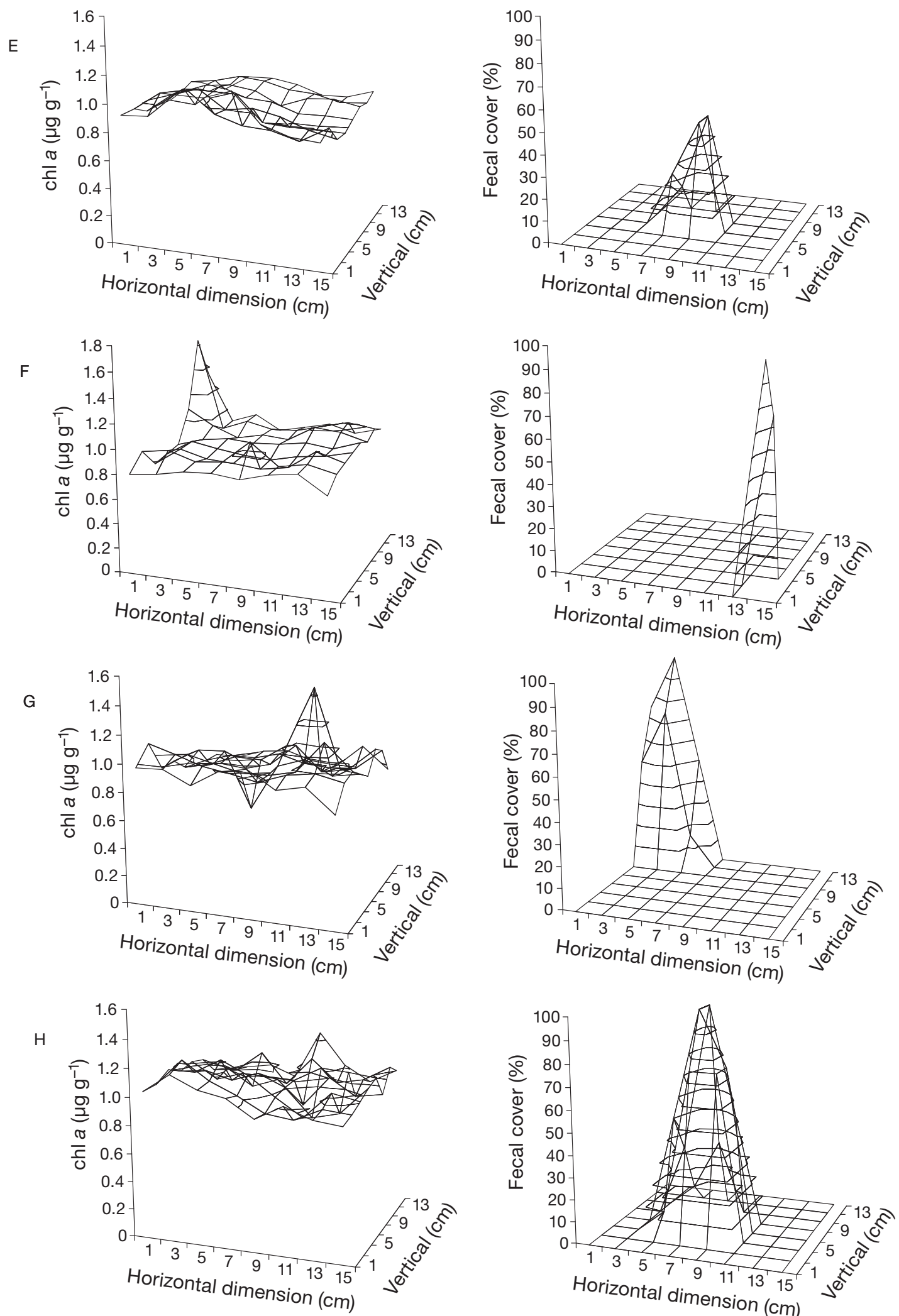

Fig. 6. Surface plots showing the sediment chlorophyll a (post-immersion) content and corresponding fecal cover (pre-immersion) of $16 \mathrm{~cm} \times 16 \mathrm{~cm}$ sampling Grids $\mathrm{E}$ to $\mathrm{H}$ (as mentioned in Fig. 1). Horizontal and vertical dimensions refer to along-transect and perpendicular (up-beach) aspects of each grid, respectively 


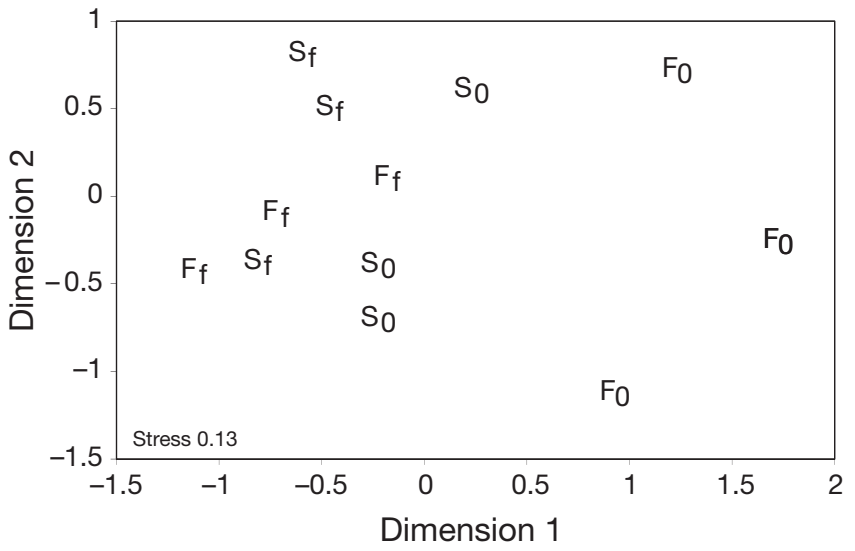

Fig. 7. Non-metric multidimensional scaling plot for the $18 \mathrm{~S}$ rDNA DGGE analysis, pre-immersion (subscript 0) and postimmersion (subscript f) fecal (F) and surface sediments (S)

patchiness in surface sediments. We observed a positive autocorrelation at a small spatial scale $(\sim 2.4 \mathrm{~cm}$ between sampling sites), indicating that samples taken at that distance tended to be similar in biomass. Patch radius was estimated to be $\sim 7 \mathrm{~cm}$ (as indicated by the line crossing the $x$-axis on the correlogram, our Fig. 4A; Sandulli \& Pinckney 1999). Assuming circular patch shape, we estimate an average patch size of $\sim 154 \mathrm{~cm}^{2}$. Similar studies employing spatial autocorrelation analyses likewise detected microalgal patches in temperate intertidal sediments; Blanchard (1990) noted an average patch size of $79 \mathrm{~cm}^{2}$ and Sandulli \& Pinckney (1999) found microalgal patch sizes ranging between 30 and $191 \mathrm{~cm}^{2}$. Jesus et al. (2005) likewise detected centimeter-scale patchiness in intertidal BMA using pulse-amplitude modulated (PAM) fluorometry. At their sandy site (their site most similar to ours), patch sizes ranged between 7.3 and $40.2 \mathrm{~cm}^{2}$ (Jesus et al. 2005). Our patch size estimate falls into these broad ranges, tending toward the upper end. In the present study, the observed patchiness appears to be due to Balanoglossus aurantiacus fecal coils, areas of lower microalgal biomass. According to our transect study, the average radius for fecal mounds approximated $6 \mathrm{~cm}$, or a total patch size of about $113 \mathrm{~cm}^{2}$. Given the discontinuous nature of both the transect measurements (every $2 \mathrm{~cm}$ ) and the samples for spatial autocorrelation, this represents good general agreement with the patch size estimate from the autocorrelation analysis. These estimates also correspond with the distinct appearance (physical elevation and color difference) of the fecal coils. This agreement is important because percent fecal cover data for our correlative analyses were visually determined.
At intermediate spatial scales (40 to $80 \mathrm{~cm}$ ), negative spatial autocorrelation was detected during late low tide, indicating that transitions from high to low BMA biomass occurred within the main sampling unit $\left(1 \mathrm{~m}^{2}\right)$. Although previous studies of this nature have observed significant spatial patterning over larger spatial scales $(\geq 1 \mathrm{~m})$, attributed to sediment characteristics (Paterson et al. 2003) or sand waves (Plante et al. 1986), we did not detect significant autocorrelation at scales over $\sim 0.8 \mathrm{~m}$.

ANOSIM results illustrate that the BMA community composition of fresh Balanoglossus aurantiacus egesta was distinguishable from that of surrounding sediments. Clarke \& Warwick (2001) point out that sample types can be distinguished by ANOSIM due either to differences in mean or by marked difference in variance. Our NMDS plot suggests that the fecalsediment separation is due primarily to the latter. A few explanations might account for the greater BMA compositional variability in fecal coils. First, sediments from different depth strata, with disparate BMA communities, could be ingested. Duncan (1987) suggests that $B$. aurantiacus subducts surficial sediments to depths of 3 to $10 \mathrm{~cm}$ before ingesting, and also that these deposit feeders shift the position of their burrows and feeding funnels on a daily basis. Thus, deeper sediments are likely ingested both when the animal relocates, and to a lesser degree, in normal feeding modes. Alternatively, it is possible that coils may have been in different stages of succession. Prior studies at this site showed significant BMA recovery in as little as $3 \mathrm{~h}$ (to $\sim 20 \%$ of ambient chl a levels; Plante et al. 2010). Vopel et al. (2007) likewise observed rapid recovery of benthic phototrophs following disturbance associated with heart urchin burrowing in subtidal sediments, potentially in response to a favorable nutrient supply in freshly reworked sediment.

Despite removing individuals, disturbance can increase species evenness (and diversity) at the scale of individual patches through compensatory mortality, in which competitively dominant species suffer disproportionately following a disturbance (Connell 1978). Although differences in community structure between egesta and background sediment were indicated by DGGE and ANOSIM in the present study, diatom species richness (band number) and diversity did not differ. In part, the inability to detect significant differences despite lower absolute $S$ and $H^{\prime}$ in pre-immersion egesta could be due to the high variability in community structure among fecal samples (see previous paragraph and Fig. 7). Methodological limitations also may hinder the ability to 
detect differences in species richness among communities. Prior studies have demonstrated that specific template DNA must represent 1 to $2 \%$ of total DNA to be detected by the PCR-DGGE approach (Muyzer et al. 1993, Murray et al. 1996), thus rare species are missed and total richness is underestimated. Despite these possible limitations, differences in the relative intensity of bands and composition were distinguishable by ANOSIM. The changes in relative band intensity observed in the present study may be especially important, as it has often been observed that disturbances normally have little effect on species richness-more likely, major shifts in relative dominance and species evenness result (Reice 1994). It is better established that disturbances generate diversity at spatial scales larger (i.e. landscape scale) than that of individual patches (Sousa 2001). A different sampling design than employed in the present study, e.g. comparison of landscapes with and without deposit feeders, would be needed to test hypotheses about diversity at larger spatial scales.

Like deposit feeding, tidal immersion also appears to cause significant reduction in sedimentary microalgal biomass because chl a levels were much reduced in surface sediments collected just after tidal emersion as compared to exposed sediments during the flood stage of the previous low tide. However, this conclusion is complicated by the cyclical vertical migrations performed by epipelic diatoms and other BMA that can cause considerable variation of biomass in surface sediments over short time scales. It is thought that these migrations are confined to the uppermost sediment layers, the exact depth of which is dictated by light penetration and therefore sediment characteristics. Because we sampled to $3 \mathrm{~mm}$, if the migrations were restricted to the uppermost few millimeters, this activity would not complicate our interpretations. Fortunately, Easley et al. (2005) documented BMA vertical migrations at this study site. Although they found changes in chl a down to depths of $10 \mathrm{~mm}$ over a complete tidal cycle (including periods of sediment resuspension when inundated), they observed BMA migrations only within the top 1 to $2 \mathrm{~mm}$ of sediments (see their Fig. 2). Thus, loss of $\mathrm{chl}$ a between periods of emersion would appear to constitute a true disturbance. It is possible that removal was due to mortality, although translocation (i.e. to the water column, deeper waters, or deeper sediment strata) seems more likely. Although lab studies have indicated that abrasion can result in BMA loss (Miller 1989, Delgado et al. 1991), realistic levels of sediment transport in the field typically have failed to show significant BMA destruction (Miller 1989).
Even more apparent is that sediment transport or resuspension during periods of immersion obliterates the spatial heterogeneity in BMA biomass caused by Balanoglossus aurantiacus feeding. After tidal immersion, BMA biomass was significantly higher where fecal mounds had been, roughly matching the now lower levels in adjacent sediments. Jesus et al. (2005) noted high temporal autocorrelation in BMA biomass values during emersion, but the correlation broke down after tidal inundation, suggesting reorientation of patch dynamics during immersion. Furthermore, in the present study, BMA compositional differences in egesta were no longer detectable following tidal immersion. Visual absence of fecal coils corroborates the notion that BMA patchiness caused by $B$. aurantiacus feeding was erased.

BMA patchiness has long been recognized as an important factor to be considered in sampling design (Blanchard 1990). Variability in photosynthetically active biomass in intertidal sediments has also been recognized as an important consideration in productivity models (Perkins et al. 2001, Serodio et al. 2001). At higher trophic levels, dispersion patterns might be patchy if BMA are a limiting resource. For instance, patchiness of meiobenthic copepods has been shown to be correlated with BMA biomass (Decho \& Fleeger 1988, Sandulli \& Pinckney 1999). Other studies, however, revealed no correlations in other meiobenthic taxa or at different locales (Blanchard 1990, Pinckney \& Sandulli 1990), perhaps because BMA biomass is at times so high that it is not a limiting factor for consumers (Santos et al. 1995). BMA biomass may also create cues for invertebrate larval settling (Butman et al. 1988). For sedentary organisms, such as sedimentdwelling worms, the environment in which the larvae settle is vital to adult success. Chemical signals derived from diatom biofilms, such as EPS, could be of particular importance to species that feed heavily on BMA (Harder et al. 2002). More indirectly, BMA patchiness due to deposit feeding may influence sediment stability. Previous work has shown that erosion rates are negatively correlated with sediment chlorophyll content (Sutherland et al. 1998). The EPS produced within diatom biofilms allow them to form mat-like structures on the surface of sediment, which increase erosion thresholds and stabilize sediment (Yallop et al. 1994, Sutherland et al. 1998). Thus, heterogeneity in diatom distributions due to deposit feeding contributes to EPS patchiness; consequently, erosion is more likely to occur (Lanuru 2004, Tolhurst et al. 2006).

However, at our intertidal site, BMA biomass heterogeneity due to deposit feeding is an ephemeral 
phenomenon. Although sampling schemes conducted at low tide need to account for patchiness and spatial autocorrelation, as do total productivity models, many of the above-mentioned processes are focused during periods of tidal immersion, thus the homogenization observed in the present study suggests that patchiness at low tide holds limited significance. For instance, invertebrate recruitment, sediment resuspension, and animals grazing on BMA may be little impacted by the patchiness during aerial exposure at our study site and in similar intertidal environments. That the incoming tide homogenizes but also removes BMA biomass does, however, suggest that a significant portion of intertidal BMA production is redistributed, e.g. to the water column or deeper sediments, thereby subsidizing these adjacent ecosystems (de Jonge \& van Beusekom 1992, Malet et al. 2008).

In summary, our results demonstrate that Balanoglossus aurantiacus feeding removes BMA biomass and alters community structure, and also corroborate earlier studies showing that deposit feeding produces spatial heterogeneity. We also show that tidal inundation of our semi-protected beach reduces sediment BMA biomass and homogenizes benthic diatoms such that patchiness caused by deposit feeding is erased. To determine whether these results are generalizable, studies conducted with higher abundances or a wider taxonomic range of deposit feeders are needed. In addition, studies similar to those reported herein, but conducted in situations with minimal sediment transport, are needed to assess the significance of more persistent BMA patchiness. Our future work will employ such studies in adjacent subtidal waters. In addition, we will attempt to employ manipulative experiments to prevent resuspension within intertidal sediments at Breach Inlet or similar intertidal sites.

Acknowledgements. Funding for this research was provided by the US National Science Foundation (NSF-REU grant DBI-0552828) and the Department of Defense A.S.S.U.R.E. Program. J. Hanagriff, C. Campbell, and E. Dennis provided assistance during the field collections. This is contribution no. 377 of the Grice Marine Laboratory.

\section{LITERATURE CITED}

Aguilera A, Gómez F, Lospitao E, Amils R (2006) A molecular approach to the characterization of the eukaryotic communities of an extreme acidic environment: methods for DNA extraction and denaturing gradient gel electrophoresis analysis. Syst Appl Microbiol 29:593-605

Altschul SF, Gish W, Miller W, Myers EW, Lipman DJ (1990) Basic local alignment search tool. J Mol Biol 215:403-410
Austen I, Andersen TJ, Edelvang K (1999) The influence of benthic diatoms on the erodibility of an intertidal mudflat, the Danish Wadden Sea. Estuar Coast Shelf Sci 49: 99-111

Bianchi TS, Levinton JS (1981) Nutrition and food limitation of deposit feeders: II. Differential effects of Hydrobia totteni and Ilyanassa obsoleta on the microbial community. J Mar Res 39:547-556

> Blanchard GF (1990) Overlapping microscale dispersion patterns of meiofauna and microphytobenthos. Mar Ecol Prog Ser 68:101-111

Brey T (1991) The relative significance of biological and physical disturbance: an example from intertidal and subtidal sandy bottom communities. Estuar Coast Shelf Sci 33:339-360

Butman CA, Grassle JP, Webb CM (1988) Substrate choices made by marine larvae settling in still water and in a flume flow. Nature 333:771-773

Cary SC, Hicks BJ, Crawford NJ, Coyne KA (2006) A sensitive genetic-based detection capability for Didymosphenia geminate. Interim report: CBER Contract Report 45. Centre for Biodiversity and Ecology Research, Hamilton

Clarke KR, Gorley RN (2006) Primer v6: user's manual/tutorial. Primer-E, Plymouth

Clarke KR, Green RH (1988) Statistical design and analysis for a 'biological effects' study. Mar Ecol Prog Ser 46: 213-226

Clarke KR, Warwick RM (2001) Changes in marine communities: an approach to statistical analysis and interpretation, 2nd edn. Primer-E, Plymouth

Collins SL, Smith MD (2006) Scale-dependent interaction of fire and grazing on community heterogeneity in tallgrass prairie. Ecology 87:2058-2067

Connell JH (1978) Diversity in tropical rain forests and coral reefs. Science 199:1302-1310

de Jonge VN (1994) Wind-driven tidal and annual gross transport of mud and microphytobenthos in the Ems estuary, and its importance for the ecosystem. In: Dyer $\mathrm{KR}$, Orth RJ (eds) Changes in fluxes in estuaries: implications from science to management. International Symposium Series. Olsen \& Olsen, Fredensborg, p 29-40

$>$ de Jonge VN, van Beusekom JEE (1992) Contribution of resuspended microphytobenthos to total phytoplankton in the Ems estuary and its possible role for grazers. Neth J Sea Res 30:91-105

> Decho AW, Fleeger J (1988) Microscale dispersion of meiobenthic copepods in response to food-resource patchiness. J Exp Mar Biol Ecol 118:229-243

Decho AW, Lopez GR (1993) Exopolymer microenvironments of microbial flora: multiple and interactive effects on trophic relationships. Limnol Oceanogr 38:1633-1645

> Delgado M, de Jonge VN, Peletier H (1991) Effect of sand movement on the growth of benthic diatoms. J Exp Mar Biol Ecol 145:221-231

$>$ Duncan PB (1987) Burrow structure and burrowing activity of the funnel-feeding enteropneust Balanoglossus aurantiacus in Bogue Sound, North Carolina, USA. PSZNI: Mar Ecol 8:75-95

Easley JT, Hymel SN, Plante CJ (2005) Temporal patterns of benthic microalgal migration on a semi-protected beach. Estuar Coast Shelf Sci 64:486-496

Fenchel T (1972) Aspects of decomposer food chains in marine benthos. Verh Dtsch Zool Ges 65:14-22

Grippo MA, Fleeger JW, Rabalais NN, Condrey R, Carman KR (2010) Contribution of phytoplankton and benthic 
microalgae to inner shelf sediments of the north-central Gulf of Mexico. Cont Shelf Res 30:456-466

> Hagerthey SE, Defew EC, Paterson DM (2002) Influence of Corophium volutator and Hydrobia ulvae on intertidal benthic diatom assemblages under different nutrient and temperature regimes. Mar Ecol Prog Ser 245:47-59

- Harder T, Lam C, Qian P (2002) Induction of larval settlement in the polychaete Hydroides elegans by marine biofilms: an investigation of monospecific diatom films as settlement cues. Mar Ecol Prog Ser 229:105-112

Hargrave BT (1970) The utilisation of benthic microflora by Hyalella azteca (Amphipoda). J Anim Ecol 39:427-437

$>$ Harrison S, Inouye BD, Safford HD (2003) Ecological heterogeneity in the effects of grazing and fire on grassland diversity. Conserv Biol 17:837-845

Hillebrand $\mathrm{H}$ (2008) Grazing regulates the spatial variability of periphyton biomass. Ecology 89:165-173

- Holland AF, Zingmark R, Dean J (1974) Quantitative evidence concerning the stabilization of sediments by marine benthic diatoms. Mar Biol 27:191-196

> Jesus B, Brotas V, Marani M, Paterson DM (2005) Spatial dynamics of microphytobenthos determined by PAM fluorescence. Estuar Coast Shelf Sci 65:30-42

Katrak G, Bird FL (2003) Comparative effects of the large bioturbators, Trypaea australiensis and Heloecius cordiformis, on intertidal sediments of Western Port, Victoria, Australia. Mar Freshw Res 54:701-708

> Kofoed LH (1975) The feeding biology of Hydrobia ventrosa (Montagu). I. The assimilation of different components of food. J Exp Mar Biol Ecol 19:233-241

Lanuru M (2004) The spatial and temporal patterns of erodibility of an intertidal flat in the East Frisian Wadden Sea, Germany. PhD dissertation, University of Kiel

- MacIntyre HL, Geider RJ, Miller DC (1996) Microphytobenthos: the ecological roles of the 'secret garden' of unvegetated, shallow-water marine habitats. I. Distribution, abundance and primary production. Estuaries 19:186-201

Malet N, Sauriau PG, Ryckaert M, Malestroit P, Guillou G (2008) Dynamics and sources of suspended particulate organic matter in the Marennes-Oleron oyster farming bay: insights from stable isotopes and microalgae ecology. Estuar Coast Shelf Sci 78:576-586

> McClatchie S, Juniper SK, Knox GA (1982) Structure of a mud-flat diatom community in the Avon-Heathcote Estuary, New Zealand. N Z J Mar Freshw Res 16: 299-309

> Meadows PS, Anderson JG (1968) Micro-organisms attached to marine sand grains. J Mar Biol Assoc UK 48:161-175

Miller DC (1989) Abrasion effects on microbes in sandy sediments. Mar Ecol Prog Ser 55:73-82

> Miller DC, Geider RJ, MacIntyre HL (1996) Microphytobenthos: the ecological role of the 'secret garden' of unvegetated, shallow-water marine habitats. II. Role in sediment stability and shallow-water food webs. Estuaries 19: 202-212

> Murray AE, Hollibaugh JT, Orrego C (1996) Phylogenetic compositions of bacterioplankton from two California estuaries compared by denaturing gradient gel electrophoresis of 16S rDNA fragments. Appl Environ Microbiol 62:2676-2680

> Muyzer G, de Waal EC, Uitterlinden AG (1993) Profiling of complex microbial populations by denaturing gradient gel electrophoresis analysis of polymerase chain reaction-amplified genes coding for 16S rRNA. Appl Environ Microbiol 59:695-700
Nielsen MV, Kofoed LH (1982) Selective feeding and episammic browsing by the deposit-feeding amphipod Corophium volutator. Mar Ecol Prog Ser 10:81-88

Paterson DM, Perkins RG, Consalvey M, Underwood GJC (2003) Ecosystem function, cell micro-cycling and the structure of transient biofilms. In: Krumbein WE, Paterson DM, Zavarzin GA (eds) Fossil and recent biofilms. A natural history of life on Earth. Kluwer Academic Publishers, Dordrecht, p 47-63

> Perkins RG, Underwood GJC, Brotas V, Snow GC, Jesus B, Ribeiro L (2001) Responses of microphytobenthos to light: primary production and carbohydrate allocation over an emersion period. Mar Ecol Prog Ser 223:101-112

Pinckney J, Sandulli R (1990) Spatial autocorrelation analysis of meiofaunal and microalgal populations on an intertidal sandflat: scale linkage between consumers and resources. Estuar Coast Shelf Sci 30:341-353

> Plante CJ, Wilde SB (2004) Biotic disturbance, recolonization, and early succession of bacterial assemblages in intertidal sediments. Microb Ecol 48:154-166

Plante R, Plante-Cuny MR, Reys JP (1986) Photosynthetic pigments of sandy sediments on the north Mediterranean coast: their spatial distribution and its effect on sampling strategies. Mar Ecol Prog Ser 34:133-141

> Plante C, Feipel S, Wilkie J (2010) Disturbance effects of deposit feeding on microalgal community structure and mechanisms of recolonization. J Phycol 46:907-916

> Powell SM, Riddle MJ, Snape I, Stark JS (2005) Location and DGGE methodology can influence interpretation of field experimental studies on the response to hydrocarbons by Antarctic benthic microbial community. Antarct Sci 17: 353-360

> Rangel TFLVB, Diniz-Filho JAF, Bini LM (2006) Towards an integrated computational tool for spatial analysis in macroecology and biogeography. Glob Ecol Biogeogr 15: 321-327

> Rees GN, Baldwin DS, Watson GO, Perryman S, Nielsen DL (2004) Ordination and significance testing of microbial community composition derived from terminal restriction fragment length polymorphisms: application of multivariate statistics. Antonie van Leeuwenhoek 86:339-347

Reice SR (1994) Nonequilibrium determinants of biological community structure. Am Sci 82:424-435

Rhoads DC, Boyer LF (1982) The effects of marine benthos on physical properties of sediment: a successional perspective. In: McCall PL, Tevesz MJS (eds) Animal-sediment relations, Vol 2. The biogenic alteration of sediments. Plenum Press, New York, NY, p 3-52

Rogers WE, Hartnett DC (2001) Vegetation responses to different spatial patterns of soil disturbance in burned and unburned tallgrass prairie. Plant Ecol 155:99-109

Sandulli R, Pinckney J (1999) Patch sizes and spatial patterns of meiobenthic copepods and benthic microalgae in sandy sediments: a microscale approach. J Sea Res 41:179-187

Santos PJP, Castel J, Souza-Santos LP (1995) Microphytobenthic patches and their influence on meiofaunal distribution. Cah Biol Mar 36:133-139

Serodio J, Silva JM, Catarino F (2001) Use of in vivo chlorophyll a fluorescence to quantify short-term variations in the productive biomass of intertidal microphytobenthos. Mar Ecol Prog Ser 218:45-61

> Shimeta J, Sisson JD (1999) Taxon-specific tidal resuspension of protists into the subtidal benthic boundary layer of a coastal embayment. Mar Ecol Prog Ser 177:51-62 
Smith D, Hughes RG, Cox EJ (1996) Predation on epipelic diatoms by the amphipod Corophium volutator and the polychaete Nereis diversicolor. Mar Ecol Prog Ser 145: 53-61

Sommer U (2000) Benthic microalgal diversity enhanced by spatial heterogeneity of grazing. Oecologia 122:284-287

Sousa WP (2001) Natural disturbance and the dynamics of marine benthic communities. In: Bertness MD, Gaines SD, Hay ME (eds) Marine community ecology. Sinauer Associates, Sunderland, MA, p 85-130

Stocum ET, Plante CJ (2006) The effect of artificial defaunation on bacterial assemblages of intertidal sediments. J Exp Mar Biol Ecol 337:147-158

Sutherland TF, Grant J, Amos CL (1998) The effect of carbohydrate production by the diatom Nitzschia curvilineata on the erodibility of sediment. Limnol Oceanogr 43: $65-72$

Tolhurst TJ, Defew EC, de Brouwer JFC, Wolstein K, Stal LJ, Paterson DM (2006) Small-scale temporal and spatial variability in the erosion threshold and properties of cohesive intertidal sediments. Cont Shelf Res 26:351-362

Turner MG (2005) Landscape ecology: What is the state of the science? Annu Rev Ecol Evol Syst 36:319-344

Underwood GJC, Paterson DM (1993) Seasonal changes in diatom biomass, sediment stability and biogenic stabilization in the Severn Estuary. J Mar Biol Assoc UK 73: 871-887

Editorial responsibility: Matthias Seaman, Oldendorf/Luhe, Germany van Hannen EJ, Veninga M, Bloem J, Gons HJ, Laanbroek HJ (1999) Genetic changes in the bacterial community structure associated with protistan grazers. Arch Hydrobiol 145:25-38

Veen GF, Blair JM, Smith MD, Collins SL (2008) Influence of grazing and fire frequency on small-scale plant community structure and resource variability in native tallgrass prairie. Oikos 117:859-866

Vopel K, Vopel A, Thistle D, Hancock N (2007) Effects of spatangoid urchins on $\mathrm{O}_{2}$ supply into coastal sediment. Mar Ecol Prog Ser 333:161-171

White PS, Pickett STA (1985) Natural disturbance and patch dynamics: an introduction. In: Pickett STA, White PS (eds) The ecology of natural disturbances and patch dynamics. Academic Press, London, p 3-13

Wilde SB, Plante CJ (2002) Spatial heterogeneity of bacterial assemblages in marine sediments: the influence of deposit feeding by Balanoglossus aurantiacus. Estuar Coast Shelf Sci 55:97-107

> Yallop ML, de Winder B, Paterson DM, Stal LJ (1994) Comparative structure, primary production and biogenic stabilization of cohesive and non-cohesive marine sediments inhabited by microphytobenthos. Estuar Coast Shelf Sci 39:565-582

> Yingst JY (1976) The utilization of organic matter in shallow marine sediments by an epibenthic deposit-feeding holothurian. J Exp Mar Biol Ecol 23:55-69

Submitted: March 23, 2011; Accepted: July 29, 2011 Proofs received from author(s): October 17, 2011 